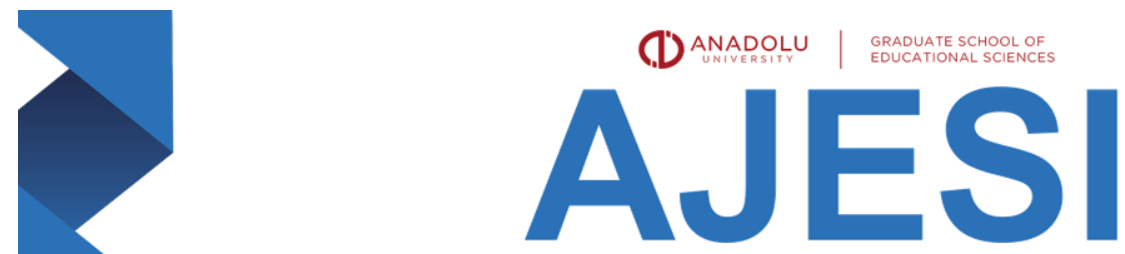

ANADOLU JOURNAL OF EDUCATIONAL SCIENCES INTERNATIONAL

DOI: 10.18039/ajesi.809356

The Validity and Reliability Study of the Attitude of Claiming Rights Scale ${ }^{1}$

Püren AKÇAY², Gül GÜLER ${ }^{3}$

Date Submitted: 13.10.2020 Date Accepted: 10.05.2021

Type $^{4}$ : Research Article

\begin{abstract}
The purpose of the study was to develop a scale to determined university students attitudes of claiming right. The draft scale, created for this purpose, was presented to the experts to get their opinions. The 46-item draft scale was applied to 462 students studying in the law, education, medical engineering faculties of a university. The data obtained from the application reached the analysis stage. In this study, which was carried out to measure the attitudes of university students towards claiming rights, the trial form of the 33-item scale was applied to 462 university students studying in various faculties. The reliability validity studies were carried out on the remaining 453 students. As a result of exploratory factor analysis promax rotation, a 4-factor structure consisting of 20 items was obtained. The total variance explained by 4 factors is $54,019 \%$. The total variance explained by each factor was found to be $29,295 \%, 10,165 \%, 7,717 \%, 6,842 \%$, respectively. Then, confirmatory factor analysis was performed to test the structure revealed by exploratory factor analysis in a different sample. Confirmatory factor analysis study was applied to the data obtained from 703 university students. It was determined that all factor loads in the CFA model were statistically significant $(p<0.05)$. Fit indices show that the scale is valid reliable to be used for different sample groups. Factor structure of HATÖ has been confirmed as 4 factors. These factors are named as "Claiming Rights", "Right to Education", "Ways to Claiming Rights", "Results of Claiming Rights". As a result of the reliability analysis of the final form of the scale, the alpha coefficient was found to be 0.88 .
\end{abstract}

Keywords: attitude, claiming rights, reliability, validity

Cite: Akçay, P., \& Güler, G. (2021). The validity and reliability study of the attitude of seeking rights scale. Anadolu Journal of Educational Sciences International, 11(2), 529-548. https://doi.org/10.18039/ajesi.809356

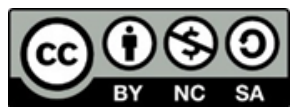

\footnotetext{
1 The article was presented as a verbal statement at the 12th World Conference on Educational Sciences (WCES) on February 06-08, 2020.

2 (Corresponding author) Assist. Prof., Istanbul Aydin University, Faculty of Educaiton, Educational Sciences, Turkey, purenakcay@aydin.edu.tr, ORCID: 0000-0002-0087-7561.

3 Assist. Prof., Istanbul Aydin University, Faculty of Educaiton, Basic Education, Turkey, gulguler@aydin.edu.tr, ORCID: 0000-0001-8626-4901.

4 This research study was conducted with Research Ethics Committee approval of Istanbul Aydin University, Faculty of Education, dated 19.02.2018 and issue number 2018/6.
} 


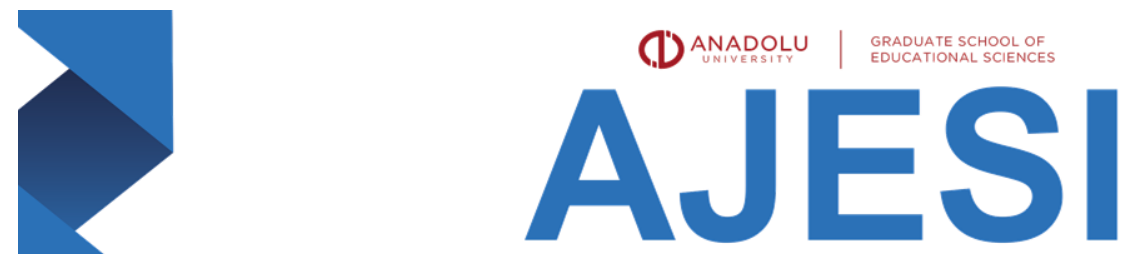

ANADOLU JOURNAL OF EDUCATIONAL SCIENCES INTERNATIONAL

DOI: 10.18039/ajesi.809356

\title{
Hak Arama Tutum Ölçeğinin Geçerlik ve Güvenirlik Çalışması ${ }^{1}$
}

\author{
Püren AKÇAY², Gül GÜLER ${ }^{3}$
}

Gönderim Tarihi: 13.10.2020 Kabul Tarihi: 10.05.2021

Türü4: Araştırma Makalesi

Öz

Bu araştırmada, üniversite öğrencilerinin hak arama tutumlarının belirlenebilmesi için bir ölçme aracı geliştirmek amaçlanmıştır. Bu amaçla oluşturulan taslak ölçek, görüşlerini almak üzere alan uzmanlarına sunulmuştur. Oluşturulan 46 maddelik taslak ölçek uzman görüşüne sunulmuş ve uzman görüşler doğrultusunda gerekli değişikliklerin yapılmasıyla 33 maddelik bir form elde edilmiştir. Bu ölçek formu bir vakıf üniversitesinin hukuk, eğitim, tıp ve mühendislik fakültelerinde öğrenim gören 462 öğrenci üzerinde uygulanmış ve uygulamadan elde edilen veriler analiz aşamasına gelinmiştir. Geçerlik ve güvenirlik analizleri 453 öğrenci üzerinden gerçekleştirilmiştir. Açımlayıcı faktör analizi (AFA) ve promax döndürme işlemi sonucu 20 maddeden oluşan dört faktörlü bir yapı elde edilmiştir. Dört faktörün açıkladığı toplam varyans \%54,019'dur. Her bir faktörün açıkladığı toplam varyans sırasıyla, \%29,295, $\% 10,165, \% 7,717, \% 6,842$ olarak bulunmuştur. Daha sonra AFA ile ortaya konulan yapıyı farklı bir örneklemde test etmek için DFA yapılmıştır. DFA çalışması 703 üniversite öğrencisi üzerinden ede edilen verilere uygulanmıştır. DFA modelindeki tüm faktör yüklerinin istatistiksel olarak manidar olduğu belirlenmiştir $(p<.05)$. DFA ile hesaplanan uyum indeksleri, ölçeğin farklı örneklem grupları için de kullanılabilir derecede geçerli ve güvenilir olduğunu göstermektedir. HATÖ'nin faktör yapısı dört faktör olarak doğrulanmıştır ve bu faktörler sırasıyla "Hak Arama", "Eğitim Hakkı", 'Hak Arama Yolları" ve "Hak Arama Sonucu" olarak adlandırılmıştır. Ölçek nihai formunun güvenirlik analizi sonucunda alfa katsayısının .88 olduğu bulunmuştur.

Anahtar kelimeler: geçerlilik, güvenilirlik, hak arama, tutum

Atıf: Akçay, P. ve Güler, G. (2021). Hak arama tutum ölçeğinin geçerlik ve güvenirlik çalışması. Anadolu Journal of Educational Sciences International, 11(2), 529-548. https://doi.org/10.18039/ajesi.809356

\footnotetext{
${ }^{1}$ Makale 06-08 Şubat 2020 tarihinde, 12th World Conference on Educational Sciences'ta (WCES) sözlü bildiri olarak sunulmuştur.

2 Dr. Öğr. Üyesi, İstanbul Aydın Üniversitesi, Eğitim Fakültesi, Eğitim Bilimleri Bölümü, Türkiye, purenakcay@aydin.edu.tr, ORCID: 0000-0002-0087-7561.

3 Dr. Öğr. Üyesi, İstanbul Aydın Üniversitesi, Eğitim Fakültesi, Temel Eğitim Bölümü, Türkiye, gulguler@aydin.edu.tr, ORCID: 0000-0001-8626-4901.

${ }^{4}$ Bu araştırma, İstanbul Aydın Üniversitesi, Etik Kurulu'nun 19.02.2018 tarih ve 2018/6 sayılı onayı ile yapılmıştır.
} 


\section{Giriş}

Hak arama özgürlüğü ve hak arama yollarının, sorumluluk sahibi olan yetkililerin yükümlülüklerini yerine getirmelerinin sağlayan bir denetim işlevi mevcuttur. Bu doğrultuda hak aramaya ilişkin olumlu tutumlar, bu dolaylı denetim işlevinin yerine getirilmesi konusunda önem arz etmektedir. Toplumun demokratik ve özgürlükçü yapısını oluşturacak genç nesilde yasal yollarla hak aramaya yönelik olumlu tutumunun yerleşmiş olması, demokrasi kültürünün oluşmasını ve devamlılığını destekleyecektir. Bu doğrultuda, yükseköğretim kurumlarının öznesi konumunda olan üniversite öğrencilerinin hak arama tutumlarının belirleyecek bir ölçek geliştirmeyi amaçlayan bu araştırmada, hak arama özgürlüğü, hak arama yolları ve eğitim hakkı araştırmanın kuramsal temelini oluşturmaktadır. Hak arama özgürlüğü, pozitif hukukun kişilere tanıdığı hakların temel şartı ve şekli garantörü olarak kabul edilmektedir (Kaboğlu, 1999). Hak arama özgürlüğü, anayasa ve kanunlarda düzenlenen tüm hak ve özgürlüklerin sağlanmasına ve hayat bulmasına yöneliktir. Bu nedenle hak arama özgürlüğü, diğer hakların elde edilebilmesi için başlı başına bir teminat rolü üstlenmektedir.

Hak arama özgürlüğünün var olduğunu gösteren en önemli unsurlar, haklarını koruması yönünde uygun ve çeşitli başvuru yollarının bulunması ve bu başvuru yollarını kolayca kullanılabilmesidir. İdare makamlarına yapılan idari başvurular, meclise yapılan siyasal başvurular ve mahkemelere yapılan yargısal başvurular hak arama özgürlüğünün yasal oluşumlarıdır. Hakların hukuki başvuru yolları vasıtasıyla aranması asıl yöntemdir. Ancak yaygın olmasa da diğer hak arama yolları kullanılarak da hak aramak mümkündür. Diğer hak arama yolları, hukukun tanıdığı fakat hukuk dışı ortaya çıkan ve aslında doğrudan bir hak arama yolu olmayıp, yine de hak aramaya imkân tanıyan yöntemleri ifade eder (Kaboğlu, 1999; Özbilgen ve Çoban, 1995). Bu yollar, hukuki yollarla hak arama özgürlüklerinin tam olarak kullanılamadığında veya hukuki hak arama yolları yetersiz kaldığında önemli işleve sahiptir. Kamuoyu baskısı oluşturma, gösteri ve yürüyüş hakkının kullanılması ve sivil toplum kuruluşlarının faaliyetleri, hukuki hak arama yollarının dışında kalan en yaygın hak arama yollarındandır.

Bireyin ve toplumun gelişmesi, herkesin ilgi ve yeteneğine göre eğitim ve öğrenim görme hakkının sağlanması yoluyla mümkün olabilecektir. Hak ve özgürlüklere ilişkin evrensel temel ilkeler, eğitim düzeyi yüksek toplumlarda vücut bulabilir (Akyüz, 2001). Güçlendirici bir hak olarak eğitim, bilinç ve farkındalığı yüksek bir vatandaş profili oluşturur (Uyar, 2006). Eğitim, temel insan haklarının ve özgürlüklerin kavranmasında, özümsenmesinde, uygulanmaya konulmasında, geliştirilmesinde ve korunmasında en etkili araçtır. Bu çerçevede eğitim hakkının tüm haklar içinde ayrı bir önemi ve rolü vardır (Karaman Kepenekçi, 2007). Hak bilincinin kazandırılması en için en uygun yolun eğitim olduğu kabul edildiğinde, devletin öncelikle eğitim hakkı ve özgürlüğünü, hukuki anlamda tanınması, ihlallere karşı koruması ve eğitim hakkının ve unsurlarının hayata geçirilmesi için üzerine düşen yükümlülükleri yerine getirmesi gerekmektedir (Akdağ, 1999). Demokrasinin gerektirdiği bilgi, tutum ve davranışlar okulda deneyimlenerek yerleşir (Dewey, 2004; Farrel, 1998; Gülmez, 199; Hotaman, 2009). Bununla birlikte birey, ancak demokratik tutum ve davranışların hüküm sürdüğü ortamlarda demokratik tutum sahibi olabilir (San, 1985).

Hak arama tutum ve davranışı, demokratik tutumlar arasında eyleme geçirmeye en fazla yatkın olanlarındır. Demokratik tutum, kişinin başkalarının haklarına ve kişiliğine saygı göstermesi, herkese karşı adaletli davranması, sorumluluk sahibi olması, eşit, açık görüşlü, dürüst, hoşgörülü, işbirlikçi, rehber, yardımsever olması ve bunları davranış haline getirme becerisi olarak tanımlanmaktadır (Demirsöz, 2010). Demokratik tutumlar ve davranışlar 
kazandırmada eğitim temel bir araç olarak kabul edilmektedir (Şahin, 2016). Demokratik eğitim düşüncesinin temellerini atan düşünür Dewey'e (1937) göre, demokrasi sadece bir yönetim biçimi değil, bireysel ve toplumsal anlamda bir yaşayış şeklidir. Demokrasi aynı zamanda insanlar arasındaki ilişkiler üzerinde temellendirilmiş ve bireyin kişilik gelişimini tamamlaması ve varolması için de esas olan bir araç niteliğindedir.

Ülkemizde bu konuda yapılan araştırmalar genellikle eğitim fakültesi öğrencilerinin demokratik tutumlarını belirlemeye yöneliktir (Akın ve Özdemir, 2009; Aydemir ve Aksoy, 2010; Bulut, 2006; Büyükkaragöz, 1995; Demoulin ve Kolstad, 2000; Dilekmen, 2000; Ekici, 2014; Elkatmış ve Toptaş, 2015; Ercoşkun ve Nalçacı, 2008; Erdem ve Sarıtas, 2006; Genç ve Kalafat, 2007, 2008; Gömleksiz ve Çetintaş, 2011; Gömleksiz ve Kan, 2008; Karahan ve diğerleri; 2006; Kılıç ve diğerleri, 2004; Ömerustaoğlu, 2004; Saracaloğlu ve diğ., 2004; Şahan, 2018; Toy, 2004; Ulusoy, 2007; Yanardağ, 2000). Yükseköğretimden önceki eğitim basamaklarında demokratik tutumlara yönelik araştırmaların (Çırak, 2018; Doğanay ve Sarı, 2004; Erbil ve Kocabaş, 2017; Izgar, 2013; Kaşaveklioğlu, 2013; Metin, 2002; Şahiner, 2008; Vatansever, 2017; Yıldııım ve Türkoğlu, 2017) sayısının daha az olması, demokrasinin belirtilen yaş grubu için soyut bir kavram olmasından ve demokrasi kültürünün eğitim süreçleriyle doğru orantılı olarak farklılaşacağı düşüncesi olduğu söylenebilir. Yine öğretmenlerin demokratik tutumlarını (Arslan ve Çalmaşur, 2017; Baltacı, 2019; Büyükkaragöz, 1996; Kaya, 2013; Kılıç ve diğerleri, 2004; Koç, 2008; Özdaş, Ekinci ve Bindak, 2014; Şen, 2006; Toy, 2004; Üstün, 2011; Yılmaz, 2010) ve okul yöneticilerinin demokratik tutumları belirlemeye yönelik araştırmalar da yapılmıştır (Akan, 2014; Aktaş, 2015; Gül ve Saraç, 2018; Karadağ, Baloğlu, Yalçınkayalar, 2006; Özbek, 2015; Özdemir, 2012; Özan, Türkoğlu, Şener, 2010; Vatansever Bayraktar ve Karakülçe, 2019). Bunların yanında Özdayı'nın (1998), eğitim yöneticilerinin demokratik tutumlarına yönelik ve Türkbay'ın (2005) üniversite öğretmenlerinin demokratik tutumlarına yönelik araştırmaları da mevcuttur.

Alanyazında öğrencilere yönelik mevcut demokratik tutum ölçek geliştirme çalışmaları, (Gözütok, 1995; Selvi, 2006; Sincar, Şahin ve Beycioğlu, 2019) öğretmen adaylarına yönelik yapılandırılmıştır. Öğretmen adaylarının demokratik tutumlarını belirlemek amaçı yapılan çalışmalar sayıca oldukça fazladır. Keçe ve Dinç (2015) yaptıkları araştırmada, üniversite öğrencilerinin demokratik katılımlarına ilişkin bir ölçek geliştirmişlerdir. Yurtdışında da demokratik değer ve tutumlar üzerine araştırmalar yapılmıştır (Burns-McFadden, 2011; Pereıra, Torres ve Barros, 2004; Perliger, et al. 2006; Piršl, Marušić-Štimac ve PokrajacBulian, 2007; Karvonen, 1974; Mellora ve Kennedy, 2003). Eldeki araştırmada, yapılan araştırmalardan farklı olarak, fakülte ayırt etmeksizin üniversite öğrencilerine yönelik, hak arama özgürlüğü, hak arama yolları ve eğitim hakkı kuramsal temelleri esas alınarak hak arama tutumlarına ilişkin bir ölçme aracı ölçek geliştirmek planlanmıştır.

\section{Araştırmanın Amacı ve Önemi}

Ölçek geliştirme amacıyla başlayan bu çalışmada "Hak Arama Tutum Ölçeği”ni geliştirme aşamaları ayrıntılı şekilde incelenmiş; üniversite öğrencileri örnekleminde geçerli olan ve aynı zamanda güvenilir bir ölçme aracının geliştirilerek alanyazına sunulması hedeflenmiştir. Çalışmanın hem alanyazına hem de üniversite öğrencilerinin hak arama tutumlarının geliştirilmesine katkı sağlayabileceği ve bu çerçevede yapılacak olan diğer çalışmalara da yol gösterici olacağı öngörülmektedir. 


\section{Yöntem}

$\mathrm{Bu}$ bölümde, araştırmanın amaçları doğrultusunda hangi yöntemlerin, araçların ve analiz tekniklerinin seçildiği ayrıntılı olarak verilmiştir.

\section{Örneklem}

Araştırmanın verileri, AFA çalışması için İstanbul'da yer alan altı farklı devlet ve özel üniversitenin eğitim, hukuk, diş hekimliği-tıp ve mühendislik fakültesi öğrencilerinden araştırmanın amacı doğrultusunda kolayda örnekleme yoluyla 2018-2019 bahar döneminde lisans eğitimine devam eden 462 öğrenciden elde edilmiştir. AFA çalışmasına katılan öğrencilerin \%52,8'i kız ve \%47,2'si ise erkek öğrencilerden meydana gelmektedir. DFA çalışması ise yine aynı üniversitede eğitim gören 703 öğrenciden elde edilmiştir. DFA çalışmasına katılan öğrencilerin \%51,4'ü kız öğrencilerden ve \%48,6'sı ise erkek öğrencilerden oluşmaktadır.

\section{Veri Toplama Süreci}

Üniversite öğrencilerinin hak aramaya yönelik tutumlarını ölçmek için geliştirilen ölçeğin deneme formunu hazırlamak üzere, 67 üniversite öğrencisinden eğitim hakları, hak arama özgürlüğü ve hak arama yollarını içeren bir kompozisyon yazmaları istenmiştir. Üniversite öğrencilerinin yazdıkları bu kompozisyonla birlikte literatür desteği alınarak hak aramaya ilişkin olası boyutlar göz önüne alınıp deneme formunun maddeleri oluşturulmuştur. Yazılan maddeler üç ölçme ve değerlendirme uzmanı, dört hukuk alanında öğretim üyesi, bir Türk Dili uzmanı ve araştırmayı yürütenler tarafından incelenmiştir. Uzman görüşü sonucu 46 madde olarak tasarlanan nihai deneme formu bazı maddelerin birden fazla yargı içerdiği, bazı maddelerin tutum yerine görüş ölçtüğü ve bazı maddelerin ölçülmek istenen özelliği tam olarak yansıtmadığı düşünüldüğü için 33 maddeye indirgenmiştir. Deneme formu hazırlanırken tutumun bilişsel, duyuşsal ve psikomotor öğeleri temsil edecek nitelikte oluşturulup olumlu olumsuz maddelerin dengeli dağılımı göz önünde bulundurulmuştur. Ölçeğin deneme formu "tamamen katılıyorum", "katılıyorum", "kararsızım", "katılmıyorum" ve "kesinlikle katılmıyorum" tepki seçeneklerini içeren beşli likert tipi dereceleme ölçeği şeklinde oluşturulmuştur.

Oluşturulan taslak ölçek formunun pilot uygulaması iki aşamada gerçekleştirilmiştir. Öncelikle farklı fakültelerde eğitim gören 44 öğrenciyle ön bir uygulama çalışması yapılmıştır. $\mathrm{Bu}$ uygulamayla öğrenciye ön bilgi verildikten sonra, ölçeğin öğrenciler tarafından nasıl anlaşıldığı, ölçekte yer alan ifadeler ile ilgili herhangi bir sıkıntı olup olmadığı birebir görüşülerek tespit edilmeye çalışılmıştır. Bu çalışmadan sonra gerekli düzenlemeler yapılarak deneme formunun son hali verilmiştir.

\section{Veri Analizi}

Hak Aramaya Yönelik Tutum Ölçeği (HATÖ) deneme formu 462 öğrenciden oluşan gruba uygulandıktan sonra elde edilen veriler bilgisayar ortamına aktarılmıştır. Ölçeğin yapı geçerliğini belirleme sürecinde, Açımlayıcı Faktör Analizi'nde SPSS 15.0 paket programından kullanılmıştır. Sonrasında DFA için ise LISREL 8.80 paket programından yararlanılmıştır.

Olumsuz maddeler için ters puanlama işlemi yapılmıştır. Daha sonra tek değişkenli uç değer analizi yapılmış, toplam puan üzerinden "mahalanobis uzaklığı" hesaplanmıştır ve dokuz 
öğrenciye ait veri uç değer göstermesi nedeniyle analiz dışında tutulmuştur. Kayıp veri incelemesi sonucunda ise kayıp verilerin tesadüfi olduğu bulgusuna ulaşılmış ve kayıp verilerin yerine seri ortalaması atanmıştır. İlk olarak ölçekten elde edilen puanların betimsel istatistiği incelenmiştir.

\section{Tablo 1}

HATÖ Verilerinin Betimsel İstatistiği

\begin{tabular}{lcccccccc}
\hline & Ortalama & Stan. Sapma & Varyans & Çarpıklık & Basıklık & Ranj & Minimum & Maksimum \\
\hline $\mathrm{N}=453$ & 119,84 & 13,181 & 173,76 &,- 498 &, 197 & 74 & 73 & 147 \\
\hline
\end{tabular}

33 maddelik beşli Likert tipi ölçekten alınabilecek en yüksek puan, 165 ve en düşük puan 33 puandır. HATÖ uygulaması ile elde edilen minimum puan 73, maksimum puan ise 147'dir. Tabloda yer alan betimsel istatistik değerleri incelendiğinde çarpıklık basıklık değeri \pm 1 sınırları dahilinde yer aldığından verilerin normal dağılım gösterdiği söylenebilir. HATÖ'nün madde analizi çalışmaları madde-toplam ölçek puanları korelasyonuna dayalı olarak gerçekleştirilmiştir. Yapılan analizle, ölçek puanları ile .30 ve üstünde korelasyon göstermiş maddeler seçilmiş .30'un altında olan maddeler taslak formdan çıkarılmıştır.

Ölçeğin faktör yapısını irdelenmek için açımlayıcı faktör analizinden (AFA) yararlanılmıştır. Bunun için öncelikli ölçek verilerinin faktör analizine uygunluğu araştırılmıştır. Örneklem büyüklüğünün faktör analizi için yeterliliğine Kaiser-Meyer- Olkin (KMO) ile bakılmıştır (Erkuş, 2012; Tavşancıl, 2006). Verilerin çok değişkenli normal dağılım sağlayıp sağlamadığı ise Barlett Küresellik Testi ile bakılmıştır. KMO değerinin 0.70'ten büyük ve Barlett Testi'nin ise .01 düzeyinde anlamlı çıkması beklenmektedir (Tabachnick ve Fidel, 2007). Analiz sürecinde bulunan madde ölçek korelasyonu ile alfa güvenilirlik katsayısının yüksek $(\alpha=.90)$ olmasıyla, faktörler arasında bir ilişki olabileceği düşünülmüş ve faktör yük değerlerini daha iyi açıklayabilmek için eğik döndürme yöntemlerinden olan promax döndürme yöntemi kullanılmıştır (Erkuş, 2003 ve Tatıdil, 1992). Faktör yükü .32'nin altında olan maddeler dikkate alınmamıştır ve maddelerin birden fazla faktöre yük verip vermediği incelenmiştir bir başka ifadeyle binişik olan maddeler tek tek ölçekten çıkarılıp analiz tekrarlanmıştır.

Ölçeğin AFA sonucu belirlenen dört faktörlü yapısının geçerliğine kanıt elde etmek için ve gözlenen yapının farklı bir örneklem üzerinde ne derece uyumlu olduğunu ortaya koymak amacıyla İstanbul'da yer alan altı farklı özel/vakıf ve devlet üniversitesinin eğitim, hukuk, diş hekimliği-tıp ve mühendislik fakültesinde lisans eğitimine devam eden 703 öğrenciden elde edilen veriler kullanılarak Doğrulayıcı Faktör Analizi çalışması yapılmıştır. Doğrulayıcı Faktör Analizinde modelin geçerliğini belirlemek için, Ki-Kare Uyum Testi, Yaklaşık Hataların Ortalama Karekökü (RMSEA), Normlanmış Uyum İndeksi (NFI), Karşılaştırmalı Uyum İndeksi (CFI), Uyum İyiliği İndeksi (GFI), Düzeltilmiş Uyum İyiliği İndeksi (AGFI) ve Artık Ortalamaların Karekökü (RMR) değerleri incelenmiştir (Kline, 2005).

\section{Etik Konular}

Bu araştırma için, İstanbul Aydın Üniversitesi Etik Kurul'undan 19.02.2018 tarih ve 2018/6 sayılı Etik Kurul kararı ile izin alınmıştır. Araştırma sürecinde ölçeğin deneme formu hazırlanırken, gönüllü öğrencilere araştırmanın amacı ile ilgili bilgi verildikten sonra 
çalışılmıştır. Öğrencilerin isim bilgilerinin kullanılmayacağı ve verilerin gizliliğinin titizlikle sağlanacağı ve verilerin sadece bu araştırmanın amacı doğrultusunda kullanılacağı belirtilmiştir.

\section{Bulgular}

HATÖ'nün geliştirilmesinde, 33 madde için korelasyon madde analizi yapılmıştır. Analiz sonucunda, ölçek puanları ile 0,30 ve üstünde korelasyonlu maddeler seçilmiş 0,30'un altında olan 6 madde taslak formdan çıkarıımıştır. 27 maddelik ölçeğin verilerinin faktör analizine uygunluğunu belirlemekte kullanılan Barlett Küresellik testi sonucunda ki-kare istatistik değeri manidar bulunmuştur $\left(x^{2}=5670,558, p<.05\right)$. KMO test değeri incelendiğinde ise, örneklem büyüklüğü, faktör analizi yapmak için 'iyi' düzeyde yeterli olduğu görülmüştür (0.902>0.70). AFA sonucunda, döndürme işleminden önce, özdeğeri 1'den büyük altı faktör elde edilmiştir. Altı faktörün toplam açıkladığı varyans, \%59,047'dir.

Faktörlerin açıkladığı varyanslar ise sırasıyla, \%29,260; \%8,446; \%6,264; \%5,909; $\% 4,823$; \%4,344'tür. Madde-toplam ölçek korelasyonunun ve ölçeğin alfa güvenirlik katsayısının yüksek oluşu nedeniyle ve faktör analizi sonucu bileşen matrisi de incelendiğinde neredeyse tüm maddelerin birinci faktöre yük verdiği gözlemlendiğinden faktörler arası ilişki olduğu düşünülmüştür. Bu nedenle eğik döndürme yöntemlerinden olan promax eğik döndürme yöntemi vasıtasıyla faktör analizi gerçekleştirilmiştir. Binişik madde, bir maddenin birden fazla faktöre yük vermesi anlamına gelmektedir. Aynı zamanda bu yük değerlerinin birbirine yakın olması durumunda binişik maddelerin ölçekten çıkarılması gerekmektedir (Bryman ve Cramer, 2001; Büyüköztürk, 2010). Bu ölçüte göre birden fazla faktöre yük veren yedi binişik madde $(3,8,11,14,19,20,21)$ ölçekten çıkarılmış ve 20 maddeden meydana gelen, dört faktörlü yapıya ulaşılmıştır.

\section{Şekil 1}

Özdeğer Grafiği

Scree Plot

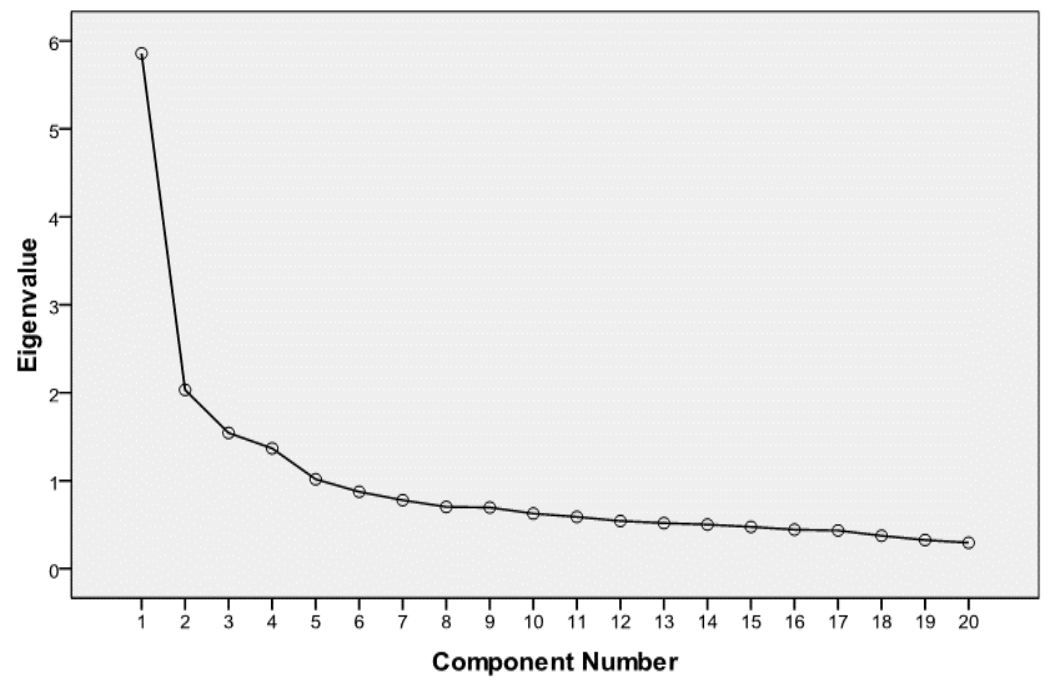

Şekil 1'de görüldüğü üzere ölçeğin dört faktörünün açıkladığı toplam varyans oranı, \%54,0193'tür. Her faktörün teker teker açıkladığı toplam varyans, sırayla \%29,295, \%10,165, 
\%7,717, \%6,842'dir. 20 maddeden oluşan ölçeğin faktör yük değerleri madde toplam ölçek korelâsyonları Tablo 2'de verilmektedir.

\section{Tablo 2}

Ölçek Maddelerinin Faktör Yükleri ve Madde-Ölçek Korelasyon Katsayıları

\begin{tabular}{|c|c|c|c|c|}
\hline & $\begin{array}{l}\text { Madde } \\
\text { No }\end{array}$ & Ölçek Maddeleri & $\begin{array}{l}\text { Madde-Ölçek } \\
\text { Korelasyonları }\end{array}$ & $\begin{array}{l}\text { Faktör } \\
\text { Yükleri }\end{array}$ \\
\hline \multirow{6}{*}{$\begin{array}{l}\text { 1. Faktör } \\
\text { Hak } \\
\text { Aramaya } \\
\text { İlişkin } \\
\text { Tutum }\end{array}$} & 6 & $\begin{array}{l}\text { Hak aramanın kışkırtıcı } \\
\text { düşünüyorum }\end{array}$ & 0,502 & 0,749 \\
\hline & 16 & $\begin{array}{l}\text { Öğrencinin hak araması öğretmenlerine karşı } \\
\text { saygısızlıktır }\end{array}$ & 0,546 & 0,728 \\
\hline & 26 & Hak arayan insanlar bana itici gelmektedir. & 0,564 & 0,726 \\
\hline & 5 & Hakkını arayanların kötü örnek olduğunu düşünüyorum & 0,605 & 0,696 \\
\hline & 13 & Hakkını arayan insanlara destek olmam & 0,542 & 0,665 \\
\hline & 15 & Başka birinin hakkının ihlal edilmesi umurumda olmaz & 0,647 & 0,643 \\
\hline \multirow{7}{*}{$\begin{array}{l}\text { 2.Faktör } \\
\text { Eğitim } \\
\text { Hakkına } \\
\text { İlişkin } \\
\text { Tutum }\end{array}$} & 2 & Eğitim hakkımın göz ardı edilmesine tahammül edemem & 0,603 & 0,810 \\
\hline & 1 & Eğitim hakkıma ilişkin ihlalleri asla kabul etmem & 0,374 & 0,772 \\
\hline & 7 & Eğitime ilişkin haklarımı aramaktan çekinmem & 0,484 & 0,732 \\
\hline & 4 & Eğitimle ilgili haklarımın ihlal edilmesini göz ardı edemem & 0,379 & 0,653 \\
\hline & 9 & Hakkımı aramak konusunda tereddüt ederim & 0,496 & 0,573 \\
\hline & 22 & $\begin{array}{l}\text { Eğitimimi etkileyecek eksiklikleri talep etmekten } \\
\text { kaçınmam }\end{array}$ & 0,464 & 0,496 \\
\hline & 12 & $\begin{array}{l}\text { Sonuç ne olursa olsun hakkımı aramış olmak beni } \\
\text { rahatlatır }\end{array}$ & 0,333 & 0,409 \\
\hline \multirow{4}{*}{$\begin{array}{l}\text { 3.Faktör } \\
\text { Hukuki Hak } \\
\text { Arama } \\
\text { Yollarına } \\
\text { İlişkin } \\
\text { Tutum }\end{array}$} & 17 & Öğrenci hakları için gösteri yapmayı anlamsız buluyorum & 0,513 & 0,759 \\
\hline & 18 & Yemek boykotuna asla katılmam & 0,349 & 0,749 \\
\hline & 10 & $\begin{array}{l}\text { Hak aramak için okulda düzenlenen gösteri yürüyüşlere } \\
\text { katılmam }\end{array}$ & 0,355 & 0,707 \\
\hline & 27 & Öğrenci hakları için gösteri yapan öğrencileri onaylamam & 0,529 & 0,697 \\
\hline \multirow{3}{*}{$\begin{array}{l}\text { 4.Faktör } \\
\text { Hak Arama } \\
\text { Davranışının } \\
\text { Sonucuna } \\
\text { İlişkin } \\
\text { Tutum }\end{array}$} & 23 & İtiraz etmenin sonucu değiştireceğini inanmıyorum & 0,617 & 0,879 \\
\hline & 24 & Karşı çıkmanın sonuca bir etkisi olacağına inanmıyorum & 0,671 & 0,866 \\
\hline & 25 & $\begin{array}{l}\text { Sorunlarımın çözüleceğine inanmadığımdan hakkımı } \\
\text { aramak için uğraşmam }\end{array}$ & 0,561 & 0,733 \\
\hline
\end{tabular}

Tablo 2'de belirtilen ölçeğin tüm maddelerin geçerlik katsayılarının hesaplamaları, madde-test korelasyon değerleri ile hesaplanmıştır. Ölçek maddelerinin korelasyon katsayıları .33 ile .67 arasında değişmektedir. Korelasyon değerlerinin .30 ile .70 arasında olması, 'orta' düzeyde korelasyon olarak kabul edilmiştir (Büyüköztürk, 2007). Bu değerlere göre, ölçekteki maddelerin tamamı ile toplam test puanları arasında, orta düzeyde $(p<.001)$ anlamlı ilişki bulunmaktadır. Başka ifadeyle, her bir madde, testin bütünü ile orta düzeyde ilişki göstermektedir. Bu sonuç da ölçek maddeleri ve ölçülen özellik arasında benzerlik olduğunun kanıtıdır.

Ölçeğin açımlayıcı faktör analizi sonucu belirlenen 4 faktörlü yapısının geçerliğine kanıt elde etmek için farkı bir örneklem üzerinden elde edilen DFA modeli Şekil 2'de verilmiştir. Şekil 2'deki DFA modelinde, faktör yüklerinin hepsinin istatistiksel olarak anlamlı olduğu görülmüştür $(p<0,05)$. 
Tablo 3

HATÖ'ye Illişkin Uyum Iyiliği Indeksleri (Schumacker ve Lomax, 2016)

\begin{tabular}{lcccc}
\hline $\begin{array}{l}\text { Indeks } \\
\text { Tipleri }\end{array}$ & $\begin{array}{c}\text { Mükemmel Uyum } \\
\text { Ölçütü }\end{array}$ & $\begin{array}{c}\text { Kabul Edilebilir } \\
\text { Uyum Ölçütü }\end{array}$ & $\begin{array}{c}\text { Elde Edilen } \\
\text { Indeksler }\end{array}$ & $\begin{array}{c}\text { Ölçüt Temelli } \\
\text { Araştırmacı Kararı }\end{array}$ \\
\hline X2/SD & $0-3$ & $3-5$ & 4,8 & Kabul Edilebilir \\
RMSEA & $.00 \leq$ değer $\leq .05$ & $.05 \leq$ değer $\leq .10$ & 0,076 & Kabul Edilebilir \\
CFI & $.95 \leq$ değer $\leq 1.00$ & $.90 \leq$ değer $\leq .95$ & 0,94 & Kabul Edilebilir \\
NNFI & $.95 \leq$ değer $\leq 1.00$ & $.90 \leq$ değer $\leq .95$ & 0,93 & Kabul Edilebilir \\
NFI & $.95 \leq$ değer $\leq 1.00$ & $.90 \leq$ değer $\leq .95$ & 0,92 & Kabul Edilebilir \\
GFI & $.95 \leq$ değer $\leq 1.00$ & $.90 \leq$ değer $\leq .95$ & 0,90 & Kabul Edilebilir \\
\hline
\end{tabular}

DFA ile hesaplanan uyum indeksleri, RMSEA=.076; $\mathrm{CFI}=.94 ; \mathrm{GFI}=.90 ; \mathrm{NFI}=.92$; $\mathrm{NNFI=.93} \mathrm{şeklinde} \mathrm{elde} \mathrm{edilmiştir.} \mathrm{Bu} \mathrm{değerlere} \mathrm{göre,} \mathrm{ölçek} \mathrm{farklı} \mathrm{çalışma} \mathrm{grupları} \mathrm{için}$ kullanılabilir düzeyde geçerlilik ve güvenirlik göstermektedir (Çokluk, Şekercioğlu ve Büyüköztürk; 2010, Kline;2005).

\section{Şekil 2}

Doğrulayıcı Faktör Analizi Modeli

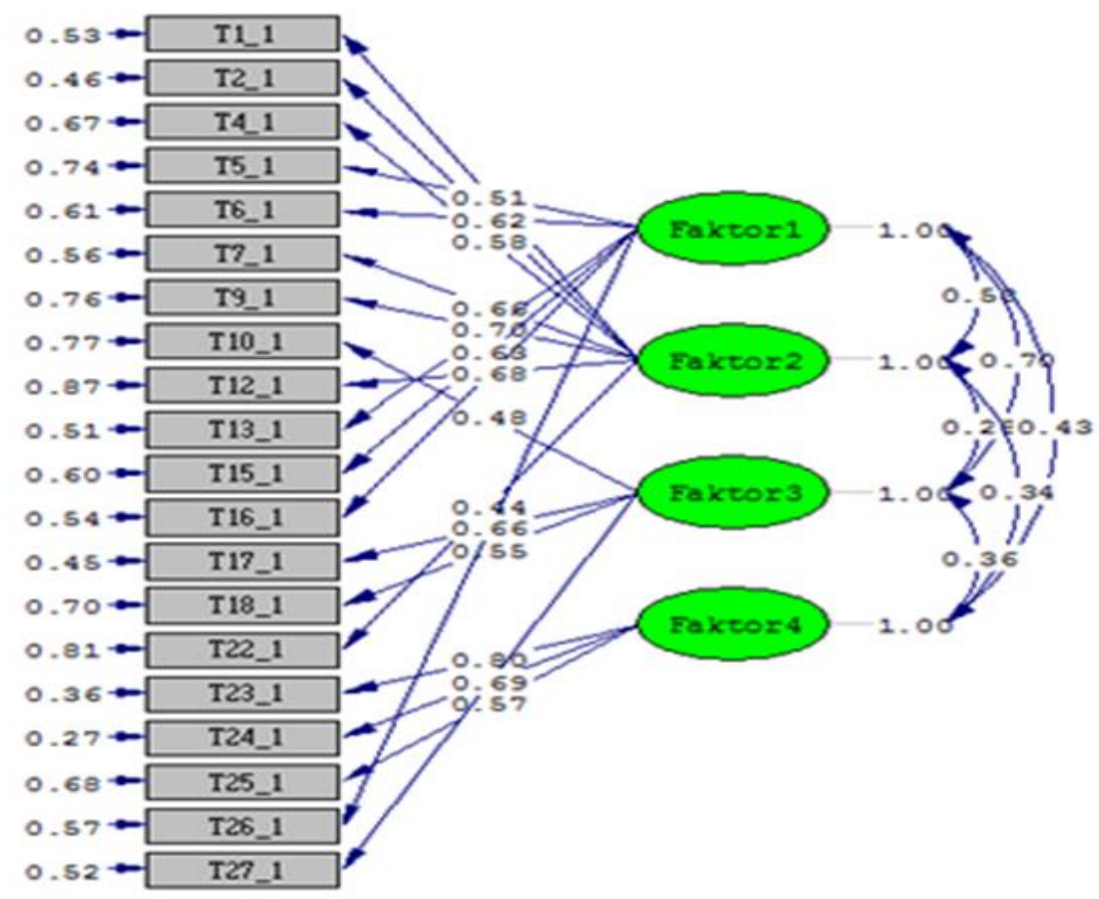

Şekil 2'de görüldüğü üzere 20 maddelik ölçeğin bütününe ait Cronbach alpha güvenirlik katsayısı $\alpha=0,88$ bulunurken, 6 maddelik birinci faktörün güvenilirlik katsayısı $\alpha=0,84 ; 7$ maddelik ikinci faktörün güvenilirlik katsayısı $\alpha=.80 ; 4$ maddelik üçüncü faktörün güvenilirlik katsayısı $\alpha=.77$ ve 3 maddeden oluşan dördüncü faktörün güvenilirlik katsayısı ise $\alpha=.75$ olarak elde edilmiştir. Bu bulgulardan da ölçeğin güvenilirliğinin yüksek olduğuna kanıt olarak sunulabilir.

HATÖ'nün doğrulayıcı faktör analizinin birinci düzeyi ile ortaya çıkan hak aramaya, eğitim hakkına, hukuki hak arama yollarına ve hak arama davranışının sonucuna ilişkin faktörler 
birleşerek üst kavram olan "hak aramayı" yansıttığını göstermek için DFA'nın ikinci düzeyi yapılmıştır (Çokluk ve diğerleri, 2010). İncelenmekte olan model için referans noktası olarak, birinci düzey DFA'da ortaya konan gizil değişken ilişkileri esas alınmıştır.

\section{Şekil 3}

Íkinci Düzey Doğrulayıcı Faktör Analizi Modeli

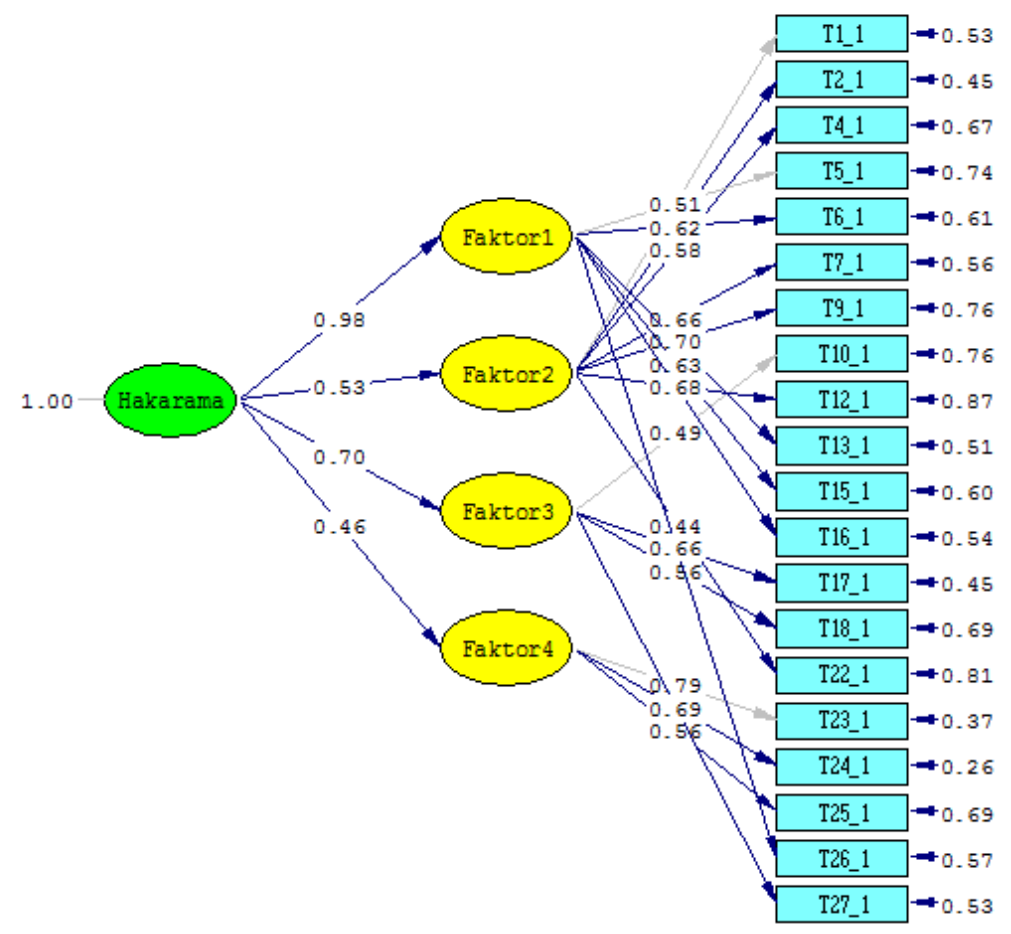

20 gösterge ve 4 örtük değişken yoluyla test edilen birinci düzey doğrulayıcı faktör modeline, ikinci düzey hak arama örtük değişkeni eklenerek, ikinci düzey faktör modelinin test edilmesi sonucunda, uyum iyiliği değerleri $[X 2(166, N=703)=681,35, p<.000, R M S E A=0,076$, $\mathrm{AGFI}=.87, \mathrm{CFI}=.93, \mathrm{NNFI}=.92, \mathrm{IFI}=.93$ ] olarak bulunmuştur. Bu değerler verinin kabul edilebilirliğini ortaya koymaktadır. İkinci düzey "hak arama" örtük değişkeni ile birinci düzey örtük değişkenler arasındaki t değerleri, en yüksek ilişkinin hak arama ve hak aramaya ilişkin tutum faktörü arasında olduğunu ortaya koymaktadır.

Elde edilen bulgular göz önünde bulundurulduğunda, üniversite öğrencilerinin hak arama tutumunun ölçülmesi için geliştirilen eğitim hakkına ilişkin tutum, hak aramaya yönelik tutum, hukuki hak arama yollarına ilişkin tutum ve hak arama davranışının sonucuna ilişkin tutum bileşenlerinden oluşan yapının yüksek geçerliğe sahip olduğu söylenebilir. Elde edilen ikinci düzey DFA sonuçları da, HATÖ'nün yapı geçerliğinin yüksek düzeyde olduğu ve ölçekten elde edilen toplam puanın anlamlı olduğunu ortaya koymaktadır.

HATÖ'nün bileşenleri arasındaki ilişki, Pearson Momentler Çarpımı Korelasyon katsayıları ile hesaplanmıştır. 


\section{Tablo 4}

HATÖ ve Bileşenleri Korelasyon Matrisi

\begin{tabular}{|c|c|c|c|c|}
\hline & Hak Arama & Eğitim Hakkı & Hukiki Hak Arama & Hak Arama Davranışının Sonucu \\
\hline HATÖ & $.81^{* *}$ & $.75^{\star *}$ & $.70^{* *}$ & $.67^{\star *}$ \\
\hline Hak Arama & - & $.49^{* *}$ & $.48^{* *}$ & $.37^{* *}$ \\
\hline Eğitim Hakkı & - & - & $.29^{\star *}$ & $.37^{\star *}$ \\
\hline Hukiki Hak Arama & - & - & - & $.31^{* *}$ \\
\hline
\end{tabular}

Tablo 4 incelendiğinde, HATÖ ve bileşenleri arasındaki korelasyon değerlerinin DFA sonucunu destekler nitelikte olduğu görülmektedir. Bileşenler arasındaki korelasyon değerleri ise 0,29-0,49 arasında olduğu görülmektedir. Bileşenler arasındaki korelasyon değerlerinin 0,80 'den küçük olması, ölçek yapısının yüksek geçerlikte olduğunu ortaya koymaktadır (Brown, 2006).

\section{Sonuç, Tartışma ve Öneriler}

Çalışma sonucunda açımlayıcı faktör analizi ve promax döndürme işlemi sonucu, tamamı 20 madde ve 4 faktörlü yapıdan oluşan bir ölçek elde edilmiştir. Ölçeğin 4 faktörünün açıkladığı varyans toplamda \%54.019'dur. Ayrıca her faktörün ayrı ayrı açıkladığı varyansın toplamı ise faktör sırasıyla, \%29.295, \%10.165, \%7,717, \%6.842 olarak bulunmuştur. Yapılan açımlayıcı faktör analizinde meydana çıkan 4 faktörlü yapıyı farklı bir örneklemde deneyimlemek için DFA uygulanmıştır. DFA çalışması 703 üniversite öğrencisi üzerinden ede edilen verilere uygulanmıştır. HATÖ'nin faktör yapısı 4 faktör olarak doğrulanmıştır ve bu faktörler sırasıyla "Hak Arama", "Eğitim Hakkı", Hak Arama Yolları" ve "Hak Arama Sonucu" olarak adlandırılmıştır. Ölçeğin son şeklinin güvenirlik analizi sonucunda alfa katsayısının ise .88 olduğu bulunmuştur.

Ölçülecek yapının tespitinde kavramsal alt yapının istatistiksel temellere dayanak oluşturulması için öncelikle AFA sonra da başka bir örneklemde DFA yapılması bu çalışmanın güvenirliği ve geçerliği açısından önemli bir dayanak noktası olmuştur (Brown, 2006). Bununla birlikte özellikle DFA çalışması ölçek toplam puanın manidarlığına ilişkin kanıt oluşturmuştur. Yapılan DFA sonuçlarına göre, ikinci düzey DFA sonuçlarının daha iyi uyum vermesi nedeniyle boyutlar bazında puan alma yerine ölçekten alınacak toplam puanı kullanmanın daha uygun olacağı görülmektedir.

Ölçekten elde dilen her bir bileşen bazında ve ölçeğin toplam güvenirlik değerlerinin 0,75 ile 0,88 arasında değiştiği görülmektedir. Bu değerlerin de ölçeğin kullanımı açısından yeterli olduğunu göstermektedir.

$\mathrm{Bu}$ çalışmayla hak aramaya yönelik bir tutum ölçeğinin alan yazına kazandırılması amaçlanmıştır. Geçerlik ve güvenirlik çalışmaları yapılmış olan HATÖ, üniversite öğrencilerinin hak aramaya yönelik tutumlarını ölçmede kullanılabilecek bir ölçme aracıdır. Toplumda demokrasi kültürünün yerleşmesi için genç nesillerde hak ve özgürlük kavramlarına ilişkin farkındalık düzeyinin artması ve hak arama tutumunun gelişmesi büyük önem arz etmektedir. $\mathrm{Bu}$ doğrultuda HATÖ, üniversite öğrencilerinin hak arama tutumlarını ortaya koyarak, hak arama tutumunu geliştirmek adına yapılması gerekenlere yol gösterici bir nitelik arz etmektedir.

Ölçeğin güvenirliğine yönelik yöntemlerden, test-tekrar test yöntemi gibi değişik güvenirlik belirleme yöntemlerine ilişkin veri toplamak ile güvenirliğinin pekiştirilmesi konu ile 
ilgili araştırma yapacak araştırmalara yapılacak önerilerin başında gelmektedir. Ölçeğin geliştirildiği eğitim öğretim dönemi ve uygulandığı örneklem grubu, çalışmanın sınırıııkları olarak görülmektedir. Ölçeğin güvenirlik düzeyinin ve de geçerliğinin aralıklı zaman dilimlerinde yeniden incelenmesi önerilebilir. Bununla birlikte farklı yaş grupları ve eğitim düzeyleri için hak aramaya yönelik tutum ölçeklerinin geliştirilmesi de alanyazına büyük katkı sağlayacağı açıktır.

\section{Araştırmacıların Katkı Oranı Beyanı}

Araştırmanın alanyazın çalışması sorumlu yazar Dr. Öğr. Üyesi Püren Akçay tarafından ve araştırmanın yöntem bölümü Dr. Öğr. Üyesi Gül Güler tarafından hazırlanmıştır. Makalenin sonuç, tartışma ve öneriler bölümü ise araştırmacılar tarafından eşit oranda çaba ile gerçekleştirilmiştir.

\section{Çatışma Beyanı}

$\mathrm{Bu}$ çalışma yürütülürken, araştırma konusu ile ilgili doğrudan bağlantısı bulunana herhangi bir kişi, kurum veya kuruluştan çalışmanın değerlendirme sürecinde çalışmayla ilgili verilecek kararı olumsuz etkileyecek maddi ya da manevi herhangi bir destek alınmadığını, ayrıca çalışmaların yazarlar tarafından bağımsız ve tarafsız bir şekilde tamamlandığını beyan ederiz. Makalenin tarafsızlığı ile ilgili bilinmesi gereken herhangi bir mali katkı ve diğer çıkar çatışması olasılığı ve ilişki alanı bulunmamaktadır. 


\section{Kaynakça}

Akan, D. (2014). Öğretmen algılarına göre ilk ve ortaokul yöneticilerinin demokratik tutumları ile okul kültürü arasındaki ilişki. Eğitim Bilimleri Araştırmaları Dergisi, 4(2), 1-84.

https://dergipark.org.tr/tr/pub/ebader/issue/44715/555640 adresinden 8.3.2019 tarihinde erişilmiştir.

Akdağ, B. (1999). Eğitim Hakkı ve Özgürlüğü Üzerine. Eğitim ve Yaşam Dergisi, 4(15), 15-18.

Akın, U. ve Özdemir, M. (2009). Öğretmen adaylarının demokratik değerlerinin çeşitli değişkenler açısından incelenmesi: Eğitim bilimleri fakültesi örneği. Ankara Üniversitesi Eğitim Bilimleri Fakültesi Dergisi, 42(2), 183-198. https://doi.org/10.1501/Egifak 0000001182 adresinden 17.5.2019 tarihinde erişilmiştir.

Arslan, A. ve Çalmaşur, H. (2017). Illkokul ve ortaokul öğretmenlerinin çok kültürlü eğitim tutumları ve demokratik tutumlarının çeşitli değişkenler açısından incelenmesi. Atatürk Üniversitesi Kazım Karabekir Eğitim Fakültesi Dergisi, 34, 90-109.

https://dergipark.org.tr/tr/pub/ataunikkefd/issue/29687/297697 adresinden 20.6.2019 tarihinde erişilmiştir.

Aktaş, S. (2015). Ortaöğretim kurumları yöneticilerinin demokratik okul kültürünü oluşturmada okulmeclisi projesine karşı tutumlarının incelenmesi [Yayımlanmamış yüksek lisans tezi]. https://iau.edu.tr adresinden 8.5.2019 tarihinde erişilmiştir.

Akyüz, E. (2001). Çocuk hakları sözleşmesinin temel ilkeleri ışı̆̆ında çocuğun eğitim hakkı. Milli Eğitim Dergisi, 3, 151, 1-25.

https://dhgm.meb.gov.tr/yayimlar/dergiler/Milli Egitim Dergisi/151/akyuz.htm adresinden 11.5.2019 tarihinde erişilmiştir.

Aydemir, H. ve Aksoy, N.D. (2010). Eğitim fakültesi öğrencilerinin demokratik tutumlarının bazı değişkenlerle ilişkisi: Malatya örneği. Erzincan Eğitim Fakültesi Dergisi, 12(1), 265-279. https://dergipark.org.tr/tr/pub/ataunikkefd/issue/29687/297697 adresinden 13.4.2019 tarihinde erişilmiştir.

Baltacı, A. ve Aydın, Y. (2019) Din kültürü ve ahlak bilgisi öğretmenlerinin demokratik tutumları, Şırnak Üniversitesi Illahiyat Fakültesi Dergisi, 10(22), 58-78. https://doi.org/10.35415/sirnakifd.470026 adresinden 15.4.2019 tarihinde erişilmiştir.

Brown, T. A. (2006). Methodology in the Social Sciences. D. A. Kenny (Ed.), Methodology in the Social Sciences. Guilford Press.

Bulut, N. (2006). Bir grup üniversite öğrencisinin demokratik tutumları ile çeşitli değişkenler arasındaki ilişkiler. Kuram ve Uygulamada Eğitim Yönetimi, 45(45), 37-59.

https://dergipark.org.tr/tr/pub/kuey/issue/10352/126768 adresinden 19.5.2019 tarihinde erişilmiştir.

Burns-McFadden, R. (2011). Urban high school students' attitudes toward democratic citizenship: A comparison of students in the NJROTC program students in traditional civics classes.

Retrieved May 10, 2019, from https://digitalcommons. wayne.edu/cgi/viewcontent.cgi?article=1269\&context=0a dissertations

Büyükkaragöz, S. (1995). Yüksek öğretim programları ve demokratik tutumlar. Türk Demokrasi Vakfı Yayınları.

Büyükkaragöz, S. ve Kesici, Ş. (1996). Öğretmenlerin hoşgörü ve demokratik tutumları. Kuram ve Uygulamada Eğitim Yönetimi Dergisi, 7(7), 353-365.

https://dergipark.org.tr/tr/pub/kuey/issue/10388/127091 adresinden 12.5.2019 tarihinde erişilmiştir.

Büyüköztürk, Ş. (2007). Sosyal bilimler için veri analizi el kitabı, istatistik araştırma deseni SPSS uygulamaları ve yorum. Pegem Akademi.

Çırak, A. (2018). 6. Sınıf öğrencilerinin temel demokratik değerlerinin çeşitli değişkenler açısından incelenmesi [Yayımlanmamış yüksek lisans tezi]. Çukurova Üniversitesi. https://cu.edu.tr/ adresinden 10.5.2019 tarihinde erişilmiştir.

Çoban, A. R. (1995). Türk hukukunda hak arama özgürlügü, [Yayımlanmamış yüksek lisans tezi]. Dokuz Eylül Üniversitesi. https://deu.edu.tr/ adresinden 10.5.2019 tarihinde erişilmiştir. 
Çokluk, Ö., Şekercioğlu, G. ve Büyüköztürk, Ş. (2010). Sosyal bilimler için çok değişkenli istatistik. Pegem Yayıncilı.

Demoulin, D.F. \& Kolstad, R. (2000). Assessing the gains of behavioral dynamics essential for success in democracy for teacher education students. College Student Journal, 34(3), 417424. Retrieved May 10, 2019, from, https://go.gale.com/ps/anonymous?id=GALE\%7CA66760563\&sid=googleScholar\&v=2.1\&it=r \&linkaccess $=a b s \& i s s n=01463934 \& p=A O N E \& s w=w$.

Dilekmen, M. (2000). Sınıf öğretmenliği öğretmen adaylarının demokratik tutumlarının çeşitli değişkenler açısından incelenmesi. II. Ulusal Öğretmen Yetiştirme Sempozyumu (10-12 Mayıs Çanakkale), Çanakkale 18 Mart Üniversitesi, 438-442.

Dewey, J. (1937) Democracy educational administration. School Society 45, 457 - 467.

Doğanay, D. ve Sarı, A. (2004). Illköğretim ikinci kademe öğrencilerine temel demokratik değerlerin kazanılmama düzeyi ve bu değerlerin kazanılması sürecinde açık ve örtük programın etkilerinin karşılaştırılması. Kuram ve Uygulamada Eğitim Yönetimi, 39(39), 356-383. https://dergipark.org.tr/tr/pub/kuey/issue/10358/126815 adresinden 15.5.2019 tarihinde erişilmiştir.

Ekici, F. Y. (2014). Öğretmen adaylarının demokratik tutumları ve demografik özellikleri arasındaki ilişkinin incelenmesi. Turkish Studies, 9(11), 593-602.

https://turkishstudies.net/turkishstudies?mod=makale $\operatorname{tr}$ ozet\&makale id=17980 adresinden 10.5.2019 tarihinde erişilmiştir.

Elkatmış, M. ve Toptaş, V. (2015). Sınıf öğretmeni adaylarının demokratik tutumlarının incelenmesi. Yüzüncü Yıl Üniversitesi Eğitim Fakültesi Dergisi, 12(1),128-144. https://dergipark.org.tr/tr/pub/yyuefd/issue/25854/272575 adresinden 14.5.2019 tarihinde erişilmiştir.

Ercoşkun, M. H. ve Nalçacı, A. (2008). Sınıf öğretmeni adaylarının empatik beceri ve demokratik tutumlarının incelenmesi. Milli Eğitim, 37,180, 204-215.

https://dhgm.meb.gov.tr/yayimlar/dergiler/Milli Egitim Dergisi/180.pdf adresinden 15.5.2019 tarihinde erişilmiştir.

Erbil, D. ve Kocabaş, A. (2017). İlkokul 3. sınıf öğrencileri için bir ölçek geliştirme çalışması: demokratik tutum ölçeği. Kastamonu Eğitim Dergisi, 25(1) , 221-232. https://dergipark.org.tr/tr/pub/kefdergi/issue/27737/309043 adresinden 14.5 .2019 tarihinde erişilmiştir.

Erkuş A. (2003). Psikometri üzerine yazılar (1. Baskı). Türk Psikologlar Derneği Yayınları.

Genç, S. Z. ve Kalafat, T. (2007). Öğretmen adaylarının demokratik tutumları ile problem çözme becerilerinin çeşitli değişkenler açısından incelenmesi. Pamukkale Üniversitesi Eğitim Fakültesi Dergisi, 2, 22. http://pauegitimdergi.pau.edu.tr/Makaleler/1257026354 Salih\%20Zeki\%20Gen\%c3\%a71,\%20 Temel\%20Kalafat2.pdf adresinden 13.5.2019 tarihinde erişilmiştir.

Genç, S. Z. ve Kalafat, T. (2008). Öğretmen adaylarının demokratik tutumları ile empatik becerilerinin değerlendirilmesi üzerine bir araştırma. Manas Üniversitesi Sosyal Bilimleri Dergisi, 10(19), 211-222. https://dergipark.org.tr/tr/pub/manassosyal/issue/49945/640049 adresinden 13.5.2019 tarihinde erişilmiştir.

Gömleksiz, M. N. ve Kan A. Ü. (2008). Eğitim fakültesi ve tezsiz yüksek lisans programlarına kayıtlı öğretmen adaylarının demokratik tutumlarının değerlendirilmesi (Fırat Üniversitesi örneği), Milli Eğitim Dergisi, 37(178), 44-63.

Gömleksiz, M.N. ve Çetintaş, S. (2011). Öğretmen adaylarının demokratik tutumları (Fırat, Dicle,7 Aralık, Cumhuriyet ve Erzincan Üniversiteleri örneği). Dicle Üniversitesi Ziya Gökalp Eğitim Fakültesi Dergisi, 2(17), 1-14. https://dergipark.org.tr/en/download/article-file/787027 adresinden 16.5.2019 tarihinde erişilmiştir.

Gözütok, F. D. (1995). Öğretmenlerin demokratik tutumları. Türk Demokrasi Vakfı Yayınları. 
Gül, İ. ve Saraç, G. (2018). Okul müdürlerinin demokratik tutumları. Uluslararası Sosyal ve Eğitim Bilimleri Dergisi, 5(10), 155-172. https://doi.org/10.20860/ijoses.435764 adresinden 21.5.2019 tarihinde erişilmiştir.

Izgar, G. (2013). Illköğretim okulu 8. sınıf öğrencilerine uygulanan değerler eğitimi programının demokratik tutum ve davranışlarına etkisi [Yayımlanmamış yüksek lisans tezi]. https://erbakan.edu.tr/ adresinden 11.5.2019 tarihinde erişilmiştir.

Kaboğlu, I. Ö (1990). Türkiye'de hukuk devletinin gelişimi. Insan Hakları Yıllığı, 1(12). TODAíE Yayınları.

Karadağ, E., Baloğlu, N. ve Yalçınkayalar, P. (2006). İlköğretim okulu yöneticilerinin öğretmenler tarafından algılanan demokratik tutumları ile öğretmenlerin demokratik değerleri üzerine ilişkisel bir araştırma. Değerler Eğitimi Dergisi, 4, 65-82.

https://dergipark.org.tr/tr/pub/ded/issue/29189/312531 adresinden 13.5.2019 tarihinde erişilmiştir.

Karahan, T. F., Sardogan, M. E., Özkamalı, E. ve Dicle, A. N. (2006). Öğretmen adaylarında demokratik tutum, nevrotik eğilimler ve kendini gerçekleştirme. Hacettepe Üniversitesi Eğitim Fakültesi Dergisi, 30(30), 149-158. https://dergipark.org.tr/tr/pub/hunefd/issue/7806/102375 adresinden 17.5.2019 tarihinde erişilmiştir.

Karaman Kepenekçi, Y. (2007) Eğitimin hukuki temelleri. (Ed. M. D. Karsı). Eğitim bilimine giriş (4. Baskı, s.51-76) içinde. Pegem Yayıncılık.

Karvonen, J. (1974). School democracy social attitudes of students teachers in finnish schools, Comparative Education Review, 18(2), 207-216. https://www.jstor.org/stable/1187212 adresinden 14.5.2019 tarihinde erişilmiştir.

Kaşaveklioğlu, S. (2013). 7.Sınıf Sosyal Bilgiler dersinde işbirliğine dayalı öğretim yönteminin kullanılmasının öğrencilerin akademik başarı ile demokratik tutum ve insan hakları algılarına etkisi. [Yayımlanmamış yüksek lisans tezi].Gazi Üniversitesi. https://gazi.edu.tr/ adresinden 11.5.2019 tarihinde erişilmiştir.

Kaya, C. (2013). Sınıf öğretmenlerinin sınıf yönetimindeki demokratik tutumlarının incelenmesi [Yayımlanmamış yüksek lisans tezi]. Atatürk Üniversitesi. https://atauni.edu.tr./ adresinden 11.5.2019 tarihinde erişilmiştir.

Keçe, M. ve Dinç, E. (2015). Demokratik katııı ölçeğinin geliştirilmesi: Geçerlik ve güvenirlik çalışması. Gazi Üniversitesi Gazi Eğitim Fakültesi Dergisi, 35(1), 177-207. http://www.gefad.gazi.edu.tr/tr/pub/issue/6771/91137 adresinden 11.5.2019 tarihinde erişilmiştir.

Kılıç, D., Ercoşkun, M. H. ve Nalçacı, A. (2004). Sınıf öğretmeni adaylarının demokratik tutumları. Türkiye Sosyal Araştırmalar Dergisi, 8(2-3), 9-19. https://dergipark.org.tr/tr/pub/yyuefd/issue/25854/272575 adresinden 13.5.2019 tarihinde erişilmiştir.

Kline, R. B. (2005). Principles practice of structural equation modeling (Second edition). The Guilford Press.

Koç, Y. (2008). Beden eğitimi öğretmenlerinin demokratik tutumlarının belirlenmesi ve çeşitli değişkenler [Yayımlanmamış yüksek lisans tezi]. Bolu İzzet Abant Üniversitesi. https://ibu.edu.tr./ adresinden 11.5.2019 tarihinde erişilmiştir.

Mellora, S., \& Kennedy, K. J. (2003). Australian Students' democratic values attitudes towards participation: indicators from the IEA civic education study. International Journal of Educational Research, 39, 525-537. Retrived May 11, 2019, from, https://www.academia.edu/27192821/Australian Students democratic values and attitudes towards participation indicators from the IEA civic education study

Metin, M. (2002). Vatandaşlık ve insan hakları dersinde demokratik tutum geliştirme ve insan hakları öğretiminin önemi [Yayımlanmamış yüksek lisans tezi]. Atatürk Üniversitesi. https://atauni.edu.tr./ adresinden 11.5.2019 tarihinde erişilmiştir.

Ömerustaoğlu, A. (2004). Felsefe grubu öğretmenleri ve diğer anabilim dallarında öğrenim gören öğrencilerin demokratik tutumlarının çeşitli değişkenler açısından incelenmesi. Sakarya 
Üniversitesi Eğitim Fakültesi Dergisi, 7, 216-226.

https://dergipark.org.tr/tr/pub/sakaefd/issue/11208/133848 adresinden 15.5.2019 tarihinde erişilmiştir.

Özan, M.B., Türkoğlu, A.Z. ve Şener, G. (2010). Okul yöneticilerinin sergiledikleri demokratik tutum ve davranışlarının öğretmenlerin motivasyonuna etkisi. Fırat Üniversitesi Sosyal Bilimler Dergisi, 20(1), 275-294. https://dergipark.org.tr/tr/pub/firatsbed/issue/45190/565888 adresinden 14.5.2019 tarihinde erişilmiştir.

Özbek, B. (2016). Öğretmenlerin okul yöneticilerinin demokratik tutum ve davranışlarına ilişkin görüşlerinin çeşitli değişkenlere göre incelenmesi. Dicle Üniversitesi Ziya Gökalp Eğitim Fakültesi Dergisi, 27, 59-70. http://dx.doi.org/10.14582/DUZGEF.677 adresinden 13.5.2019 tarihinde erişilmiştir.

Özdaş, F., Ekinci, A. ve Bindak, R. (2014). Öğretmenlerin demokrasiye ilişkin tutumlarının bazı değişkenler açısından incelenmesi. İnönü Üniversitesi Eğitim Fakültesi Dergisi, Özel Sayı, 15(3), 65-81. https://doi.org/10.17679/iuefd.15384557 adresinden 14.5.2019 tarihinde erişilmiştir.

Özdayı, N. (1998). Eğitim yöneticilerinin demokrasi ve hoşgörü tutumları ile liderlik özellikleri arasındaki ilişki. M.Ü. Atatürk Eğitim Fakültesi Eğitim Bilimleri Dergisi, 10, 221-235. https://dergipark.org.tr/tr/pub/maruaebd/issue/385/2462 adresinden 16.5.2019 tarihinde erişilmiştir.

Özdemir, A. (2012). Illköğretim okul müdürlerinin demokratik tutumlarının öğretmenlerin örgütsel bağııık algısı ile iliş̧kisi [Yayımlanmamış yüksek lisans tezi]. Yeditepe Üniversitesi. https://yeditepe.edu.tr./ adresinden 11.5.2019 tarihinde erişilmiştir.

Pereıra, C., Torres, A. R. R. \& Barros, T. S. (2004). Value systems democratic attitudes in university students. Psicologia: Teoria e Pesquisa, 20(1), 1-10. Retrived May 16, 2019, from https://www.scielo.br/pdf/ptp/v20n1/a02v20n1

Perliger, A., Canetti-Nisim, D. \& Pedahzur, A. (2006). Democratic attitudes among high-school pupils: The role played by perceptions of class climate. An International Journal of Research, Policy Practice, 17(1), 119-140. Retrived May 13, 2019, from https://www.researchgate.net/publication/233413770 Democratic attitudes among highschool pupils The role played by perceptions of class climate

Piršl, E., Marušić-Štimac, O.\& Pokrajac-Bulian, A. (2007). The attitudes of students teachers towards civic education human rights. Metodički Obzori 2(2), 19-34. Retrieved May 20, 2019, from, https://hrcak.srce.hr/file/30414

Saracaloğlu, S. A., Evin, İ. ve Varol, S. R. (2004). İzmir ilinde çeşitli kurumlarda görev yapan öğretmenler ile öğretmen adaylarının demokratik tutumları üzerine karşılaştırmalı bir araştırma. Kuram ve Uygulamada Eğitim Bilimleri, 4(2), 335-364.

https://www.researchgate.net/publication/313635251 Izmir llinde Cesitli Kurumlarda Gorev Yapan Ogretmenler ile Ogretmen Adaylarinin Demokratik Tutumlari Uzerine Karsilastirma li Bir Arastirma A Comparative Research on the Democratic Attitudes of the Te adresinden 13.5.2019 tarihinde erişilmiştir.

Schumacker, R. E. \& Lomax, R. G. (2016). A beginner's guide to structural equation modeling. Lawrence Erlbaum Associates, Inc.

Selvi, K. (2006). Developing a teacher trainees? Democratic values scale: validity reliability analyses. Social Behavior Personality: An international journal, 34(9), 1171-1178. https://doi.org/10.2224/sbp.2006.34.9.1171 adresinden 10.5.2019 tarihinde erişilmiştir.

Sincar, M., Şahin, İ. ve Beycioğlu, K. (2019). Demokratik tutum ölçeğinin geçerlik ve güvenirlik çalışması. Gaziantep Üniversitesi Eğitim Bilimleri Dergisi, 3(2), 91-100. https://dergipark.org.tr/tr/pub/guebd/issue/52560/631147 adresinden 17.5.2019 tarihinde erişilmiştir.

Şahan, G. (2018). Formasyon eğitimi alan öğretmen adaylarının demokratik tutumlarının değerlendirilmesi. Turkish Studies Volume 13(4), 1045-1056.

http://dx.doi.org/10.7827/TurkishStudies.13006 adresinden 14.5.2019 tarihinde erişilmiştir. 
Şahiner, D. G. S. (2008). Ilköğretim sosyal bilimler dersinde aktif öğrenme tekniklerinin demokratik tutumlara ve ders başarısına etkisi [Yayımlanmamış yüksek lisans tezi]. Dokuz Eylül Üniversitesi. https://deu.edu.tr./ adresinden 11.5.2019 tarihinde erişilmiştir.

Tabachnick, B. G. \& Fidel, S. L. (2001). Using multivariate statistics. Harper Collin.

Tatıdil, H. (1992). Uygulamalı çok değişkenli istatistiksel analiz. Engin Yayınları.

Tavşancıl, E. (2006). Tutumların ölçülmesi ve spss ile veri analizi. Nobel Yayın Dağıtım.

Türkbay, R. A. (2005). Üniversite öğretmenlerinin demokratik tutum ve değerleri üzerine bir araştırma [Yayımlanmamış yüksek lisans tezi]. Pamukkale Üniversitesi. https://pau.edu.tr./ adresinden 12.5.2019 tarihinde erişilmiştir.

Uyar, L. (2006). Birleşmiş Milletlerde insan hakları yorumları, insan hakları komitesi ve ekonomik, sosyal ve kültürel haklar komitesi 1981-2006. İstanbul Bilgi Üniversitesi Yayınları.

Üstün, G. (2011). Sınıf öğretmenlerinin yansıtıcı düşünme eğitimleri ile demokratik tutumları arasındaki ilişkinin incelenmesi [Yayımlanmamış yüksek lisans tezi]. Marmara Üniversitesi. https://www.marmara.edu.tr/ adresinden 12.5.2019 tarihinde erişilmiştir.

Vatansever Bayraktar, H. ve Işık A. (2017). İlkokul öğrencilerinin demokratik değerlere ilişkin tutumları. Uluslararası Katııımla Yükseköğretimde Eğitim Araştırma ve Uygulama Kongresi Bildiri Özet Kitabı, 61.

Vatansever Bayraktar H. ve Karakülçe, N. (2019). İlkokul yöneticilerinin ve sınıf öğretmenlerinin demokratik tutumlarının incelenmesi. Kesit Akademi Dergisi, 5(18), 39-59.

https://dergipark.org.tr/tr/pub/kesitakademi/issue/59820/863803 adresinden 17.5.2019 tarihinde erişilmiştir.

Yaşar, N. (2000). Insan hakları Avrupa sisteminde ve Türk hukukunda eğitim hakkı ve özgürlüğü. Filiz Kitabevi.

Yıldırım, C. ve Türkoğlu, A. (2017). Democratic citizenship attitude scale: A validity reliability study. Çukurova Üniversitesi Eğitim Fakültesi Dergisi, 46(2), 649-664. https://doi.org/10.14812/cuefd.303672 adresinden 16.5.2019 tarihinde erişilmiştir.

Yılmaz, K. (2011). İlköğretim okulu öğretmenlerinin sınıf yönetimi tarzları ile demokratik değerlere ilişkin görüşleri arasındaki ilişki. Değerler Eğitimi Dergisi, 9(21), 147-170. https://dergipark.org.tr/tr/pub/ded/issue/29179/312458 adresinden 15.5.2019 tarihinde erişilmiştir. 


\section{Extended Abstract}

\section{Introduction}

The freedom to claiming right remedies have a supervisory function that ensures that responsible authorities fulfill their obligations. Accordingly, positive attitudes towards claiming rights are important in fulfilling this indirect control function. The establishment of a positive attitude towards legal rights in the young generation, who will form the democratic liberal structure of the society, will support the formation of continuity of the culture of democracy. In this study, which aims to develop a scale that will determine the attitudes of university students who are the subjects of higher education institutions, the right to claiming right, remedies the right to education constitute the theoretical basis of the research.

Freedom to claiming rights is generally understood as the precondition procedural guarantee of rights recognized by positive law (Kaboğlu, 1999, p.95). The most important factors that show that the freedom to claiming rights exist is that there are suitable various application remedies to protect their rights that these remedies can be used easily. Administrative applications to administrative authorities, political applications to the parliament judicial applications to independent courts are legal aspects of the freedom to claiming rights. Other remedies, although recognized by law, emerge unlawfully are actually not a direct remedy, but refer to the procedures that enable prepare the environment (Çoban, 1995; Kaboğlu, 1999; Özbilgen, p. 56). Creating public pressure, exercising the right to demonstrate march, the activities of non-governmental organizations are among the most common remedies other than legal remedies.

Education is the most effective tool in understanding, adopting, applying, developing protecting fundamental human rights freedoms. In this context, the right to education has a separate importance role among all rights (Karaman-Kepenekçi, 2007). When it is accepted that education is the most appropriate way to gain awareness of rights, the state must first fulfill its obligations to recognize protect the right freedom to education to realize all other elements of the right to education (Akdağ, 1999). The knowledge, attitudes and behaviors required for a democratic environment are experienced and settled in the school environment. (Dewey, 2004; Farrel, 1998; Gülmez, 1996; Hotaman, 2009). However, the individual can develop a democratic attitude only in democratic environments (San 1985: 211).

The attitude behavior to claiming justice is one of the most prone to action among democratic attitudes. Education is accepted as an essential tool in gaining democratic attitudes behaviors (Şahin, 2016). According to Dewey (1937) who laid the foundations of the idea of democratic education, democracy is not only a form of government, but a way of life in individual social terms. It can be said that the less number of studies on democratic attitudes in pre-higher education levels is due to the fact that democracy is an abstract concept for the specified age group that democracy culture will differentiate in direct proportion to educational processes. Studies have also been conducted to determine the democratic attitudes of teachers school administrators. In addition to these, Özdayı (1998) has research studies on the democratic attitudes of education administrators Türkbay's (2005) on the democratic attitudes of university teachers. The current democratic attitude scale development studies towards students in the literature (Gözütok, 1995; Selvi, 2006; Sincar, et al. 2019) were structured for prospective teachers. Studies conducted to determine the democratic attitudes of prospective teachers' are quite numerous. Keçe and Dinç (2015) developed a scale regarding the democratic participation of university students in their study. 
In the present study, it was planned to develop a measuring instrument scale on the attitudes of claiming rights based on the theoretical foundations of freedom to claiming right, remedies right to education for university students, regardless of faculty. In this study, it was aimed to develop a measurement tool to determine the claiming right attitudes. In this direction, starting from the younger generations, it was aimed to determine the attitudes of university students to assert their rights. When it is aimed to ensure that the claiming right process runs without any obstacles for the student, determining the attitudes of the student on this matter is a priority. For this reason, it was thought that it would be more appropriate to carry out the development work of the 'Claiming Right Attitude Scale within the universities.

\section{Method}

The draft scale, which was created for this purpose, was presented to the experts to get their opinions. The 46-item draft scale was applied to 462 students studying in the law, education, medical engineering faculties of a university. The data obtained from the application reached the analysis stage. In this study, which was carried out to measure the attitudes of university students towards claiming rights, the trial form of the 33-item scale was applied to 462 university students studying in various faculties. The analyzes showed that the data of 9 students gave extreme value. The data from these students were excluded from the analysis reliability validity studies were carried out on the remaining 453 students.

\section{Findings}

As a result of exploratory factor analysis promax rotation, a 4-factor structure consisting of 20 items was obtained. The total variance explained by four factors is $54,019 \%$. The total variance explained by each factor was found to be $29,295 \%, 10,165 \%, 7,717 \%, 6,842 \%$, respectively.

Then, confirmatory factor analysis was performed to test the structure revealed by exploratory factor analysis in a different sample. A confirmatory factor analysis study was applied to the data obtained from 703 university students. It was determined that all factor loads in the CFA model were statistically significant $(p<.05)$. Fit indices show that the scale is valid reliable to be used for different sample groups. Factor structure of HATÖ has been confirmed as 4 factors. These factors are named as "Claiming Right", "Right to Education", "Ways to Claiming Right" "Results of Claiming Right". As a result of the reliability analysis of the final form of the scale, the alpha coefficient was found to be .88 .

\section{Conclusion and Discussion}

Ways of claiming right are an audit tool that enables those responsible to fulfill their obligations. Attitudes towards claiming right are important to realize this function. In order to settle the asserting right attitude in the society, the claiming right attitude should be established in the younger generations the level of awareness should be high. In this study, it was aimed to develop a measurement tool to determine the claiming right attitudes. In this direction, starting from the younger generations, it was aimed to determine the claiming right attitudes of university students. 
Factor structure of HATÖ has been confirmed as 4 factors. Among these factors, they were named as "Asserting Right", " Right to Education", Claiming Right Ways "Results of claiming Right". As a result of the reliability analysis of the scale form, the alpha coefficient was found to be 0.88 .

With this study, it is aimed to take part the scale of attitudes towards claiming rights into the literature. The validity reliability of the Claiming Rights Attitude Scale is a measurement tool that can be used to measure the attitudes of university students towards claiming rights. In addition, the research includes limitations regarding the determined sample group and the time period in which the research was conducted.

Researchers may be advised to support data collection reliability for different reliability determination methods such as test-retest method related to the reliability of the scale, also to examine the reliability validity of the scale periodically. This issue should be considered in order to keep the reliability of the scale high in the face of changing times and conditions. It should be noted; however, that developing attitude scales for claiming rights for different age groups education levels will contribute greatly to the literature. 